\title{
Microbial community comparison of different biological processes for treating the same sewage
}

\author{
Xin-Chun Liu $\cdot$ Min Yang $\cdot$ Yu Zhang $\cdot$ \\ Xiang-Ping Yang $\cdot$ Yi-Ping Gan
}

Received: 15 February 2006/ Accepted: 14 May 2006/ Published online: 22 June 2006

(C) Springer Science+Business Media B.V. 2006

\begin{abstract}
The microbial communities, including ammonia-oxidizing bacterial (AOB), eubacterial, actinomycetic and yeast communities, were investigated in two different systems by PCR-DGGE (denaturing gradient gel electrophoresis) using amplified $16 \mathrm{~S}$ rRNA gene fragments of bacteria and 26S rRNA gene fragments of yeast. The two systems, which used an anoxic-anaerobic-aerobic process $\left(\mathrm{A}_{2} \mathrm{O}\right)$ and an anoxic-aerobic process (AO), respectively, received identical sewage, operated under the same conditions and demonstrated similar treatment performance. The AOB communities of the two systems showed almost identical structures corresponding to similar ammonium removal, while bacterial, actinomycetic and yeast communities demonstrated obvious differences. The $\mathrm{A}_{2} \mathrm{O}$ system showed richer eubacterial, actinomycetic and yeast communities than the AO system. FISH results showed that the $\mathrm{AOB}$ cells in the $\mathrm{A}_{2} \mathrm{O}$ system made up $3.6 \pm 0.2 \%$ of the total bacterial population, while those in the $\mathrm{AO}$ system accounted for $1.9 \pm 0.2 \%$. Thus the existence of an anaerobic environment in the $\mathrm{A}_{2} \mathrm{O}$ system resulted in a marked increase in biodiversity.
\end{abstract}

Keywords Activated sludge - Community analysis · PCR-DGGE $\cdot$ Sewage treatment $\cdot$ Yeast

X.-C. Liu $\cdot$ M. Yang $(\bowtie) \cdot$ Y. Zhang

State Key Laboratory of Environmental Aquatic Chemistry, Research Center for Eco-Environmental Sciences, Chinese Academy of Sciences, P.O. Box 2871, Beijing 100085, China e-mail: yangmin@rcees.ac.cn

X.-P. Yang · Y.-P. Gan

Beijing Drainage Group Co., Ltd., Beijing 100020, China

\author{
Abbreviations \\ FISH Fluorescence in situ hybridization \\ DGGE Denaturing gradient gel electrophoresis \\ AOB Ammonia-oxidizing bacteria \\ $\mathrm{A}_{2} \mathrm{O} \quad$ Anoxic-anaerobic-aerobic process \\ AO Anoxic-aerobic process \\ DO Dissolved oxygen \\ HRT Hydraulic retention time \\ SRT Solid residence time \\ MLSS Mixed liquor suspended solid \\ SS Suspended solid \\ SVI Sludge volume index \\ TN Total nitrogen \\ TP Total phosphorus
}

\section{Introduction}

Activated sludge is a very complicated system, comprised of various populations including heterotrophic bacteria, autotrophic bacteria, fungi and protozoa (Madoni et al. 1993). The relationship between the microbial population composition and the treatment performance of activated sludge processes has long attracted the attention of microbial ecologists and environmental engineers, as this information might be useful for the proper design and operation of biological wastewater treatment systems. Protozoa have been studied and utilized as an important indicator for judging process performance and effluent quality since the 1970s, because these large sized microorganisms can be directly observed and identified under a microscope (Curds and Cockburn 1970; Curds 1982; 
Chen et al. 2004). However, protozoa cannot live in activated sludge systems without other smaller microorganisms as their food. Research on the smaller microorganisms has been hampered by the crude, labor-intensive and biased traditional methods, because a majority of them are not cultivatable using standard techniques (Amann et al. 1995).

The recently developed molecular biological techniques, such as denaturing gradient gel electrophoresis of polymerase chain reaction (PCR-DGGE), fluorescent in situ hybridization (FISH), etc., have made it possible to look into the microbial ecology in wastewater treatment systems without relying on cultural techniques (Paniagua-Michel et al. 2005; Zheng et al. 2005). With the help of these novel techniques, the composition and population dynamics of ammoniaoxidizing bacteria (AOB) have been investigated by many researchers, because ammonia oxidation is a rate-limiting step for biological nitrogen removal (Wagner et al. 1995). Although some results are contradictory, it is now a general view that most of the $\mathrm{AOB}$ in the engineered ammonia-rich systems belong to the genera Nitrosomonas or Nitrosospira within the class betaproteobacteria (Ballinger et al. 1998). Environmental factors like salinity, ammonia levels, etc., have been found to affect the AOB composition (Bollmann and Laanbroek 2002; Rowan et al. 2003). Research has also focused on other specific microbial populations of activated sludge, such as actinomycetes because these bacteria play important roles in sludge bulking and foaming (Madoni et al. 2000; Davenport et al. 2000).

All of the above efforts provide us a much better view of the microbial ecology in activated sludge systems. However, most of the previous studies have only focused on specific bacterial populations, such as AOB and actinomycetes, in activated sludge. Since activated sludge is a complicated ecological system harboring many different groups of microorganisms and these different groups are related with each other, it is important to analyse the composition and structure of microbial communities of different groups. Only with a comprehensive understanding of the microbial ecology in activated sludge is it possible to establish a more efficient biological wastewater treatment system and operational strategy.

In this study, microbial communities of two different systems, an anoxic-anaerobic-aerobic process $\left(\mathrm{A}_{2} \mathrm{O}\right)$ and an anoxic-aerobic process (AO), respectively, receiving identical sewage and having similar treatment performance, were determined using group- specific PCR-DGGE and subsequent sequence analysis of rRNA genes. The community structures of eubacteria,
AOB, actinomycetes, and yeast in the two systems were investigated to evaluate the effects of different designs on microbial populations. FISH was used for the determination of the ratio of $\mathrm{AOB}$ in each system with the probe NSO190.

\section{Materials and methods}

\section{Objective wastewater treatment plant}

An $\mathrm{A}_{2} \mathrm{O}$ and an $\mathrm{AO}$ process were respectively adopted in a sewage treatment plant in the eastern suburbs of Beijing, each with a treatment capacity of 500,000 tonnes/day (raw water flow rate for each process, 350,000-400,000 tonnes/day). The schematic diagram for the $\mathrm{A}_{2} \mathrm{O}$ and $\mathrm{AO}$ processes are shown in Figs. 1 and 2, respectively. The $\mathrm{A}_{2} \mathrm{O}$ system was reconstructed from another $\mathrm{AO}$ system series by changing $16.3 \%$ of the aeration tank into an anaerobic compartment. Raw sewage consisted of about $60 \%$ municipal wastewater and $40 \%$ industrial wastewater. In the $\mathrm{A}_{2} \mathrm{O}$ system, $10 \%$ of raw sewage flows into the anoxic compartment, while the remaining $90 \%$ flows into the anaerobic compartment. The hydraulic retention times (HRTs) of the anoxic, anaerobic and aerobic compartments were $1.5,1.5$, and $6.0 \mathrm{~h}$, respectively. In the AO system, the HRTs of the anoxic and aerobic compartments were 1.5 and $7.5 \mathrm{~h}$, respectively. The mixed-liquor suspended solid (MLSS) of the two systems was about $2300 \mathrm{mg} / \mathrm{l}$, and other operation conditions, such as dissolved oxygen $(2.0 \mathrm{mg} / \mathrm{l}), \mathrm{pH}(6.6)$, solid residence time (SRT, 6-12 days) and total HRT $(9.0 \mathrm{~h})$, were almost the same. The sludge recycling ratio was $100 \%$, and the internal recycling ratio was 150-200\%. The average water temperature during the sampling period was $19^{\circ} \mathrm{C}$. The influent and effluent characteristics of the two systems are listed in Table 1. The COD, BOD, $\mathrm{NH}_{4}^{+}-\mathrm{N}, \mathrm{TN}, \mathrm{TP}$, and SS were analysed according to Standard Methods for the Examination of Water and Wastewater (APHA, 1985). The flow charts of the $\mathrm{A}_{2} \mathrm{O}$ and the $\mathrm{AO}$ process are shown as Figs. 1 and 2 respectively.

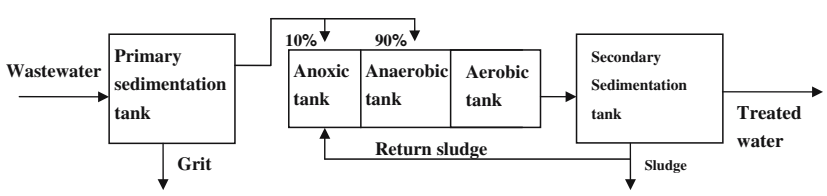

Fig. 1 Flow chart of the anoxic-anaerobic-aerobic process 


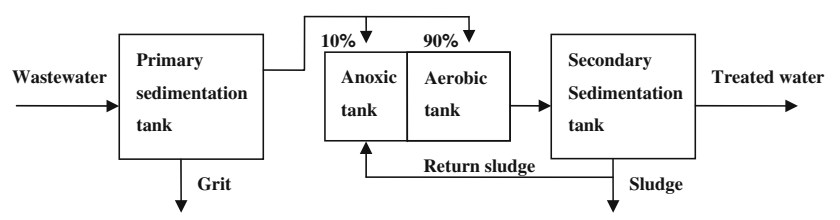

Fig. 2 Flow chart of the AO

Samples of activated sludge

Activated sludge samples were collected three times from the aeration tanks of the two systems during the summer (April, May, June 2004). Samples for FISH and DNA extraction were placed in different sterile polypropylene tubes, respectively, and taken back to the laboratory in an hour. For DNA extraction, the sludge from approximately $50 \mathrm{mg}$ (wet weight) of biomass was transferred into a 2.0-ml Eppendorf tube and centrifuged at $14,000 \times g$ for $10 \mathrm{~min}$. The supernatant was removed, and the pellets were stored at $-20^{\circ} \mathrm{C}$ until DNA extraction. The MLSS concentrations were determined on the day of sampling.

DNA extraction of bacteria and yeast

Bacteria DNA was extracted from samples in triplicate using the method of Miller et al. (1999) with a small modification at the initial step: $1 \mathrm{ml}$ phosphate buffer salt solution (100 $\mathrm{mM} \mathrm{NaH}_{2} \mathrm{PO}_{4}, \mathrm{pH}$ 8.0) was added to and mixed with the sample, and then the tube was sonicated for $30 \mathrm{~s}$ on ice.

Yeast DNA was extracted also in triplicate according to the protocol of Schloss et al. (2003)

The product from DNA extraction was verified by electrophoresis in $0.8 \%$ agarose.

\section{PCR and DGGE}

All the primers used and PCR conditions are listed in Table 2. The final concentrations of different components in the mastermix were: 15 pmol of each primer, $200 \mu \mathrm{M}$ of each deoxynucleoside triphosphate, $1 \times$ reaction buffer, $1.25 \mathrm{U} / 50 \mu \mathrm{l}$ of Taq DNA Polymerase (Promega, USA), $400 \mathrm{ng} / \mu \mathrm{l}$ of bovine serum albumin, and DNase- and RNase-free filter-sterilized water.
For bacterial population analysis, the general primers GC-338f and P518r were used to directly amplify the $16 \mathrm{~S}$ rRNA gene of bacteria by adding $2 \mu \mathrm{l}$ of extracted DNA to $48 \mu \mathrm{l}$ PCR mastermix.

The D1 region of the 26S rRNA gene of yeast was amplified by PCR using the forward primers GC-NL1 and a reverse primer LS2 according to the protocol of Cocolin et al. (2000).

For analysis of $\mathrm{AOB}$ and actinomycetic populations in activated sludge, a nested PCR technique was used in order to increase the sensitivity (Boon et al. 2002). In the first round, $1 \mu$ of extracted DNA was added to $24 \mu \mathrm{l}$ of PCR mastermix, and different primers were used, each with their own corresponding PCR protocol. During the second PCR round, $1 \mu \mathrm{l}$ of amplified product from the first round was added to $49 \mu \mathrm{l}$ of the PCR mixture and then reamplified by using their own corresponding primers and PCR protocol, shown in Table 2.

The DGGE analysis was basically performed as first described by Muyzer et al. (1993), using a DCode System apparatus (Bio-Rad Co., USA). The PCR products of the second round were loaded onto $10 \%$ (w/v) polyacrylamide gels (bisacrylamide: acrylamide $=37.5: 1)$ in $1 \times$ TAE buffer. The polyacrylamide gels were made with the denaturing gradient ranging from $38 \%$ to $50 \%$ denaturant (where $100 \%$ denaturant contains $7 \mathrm{M}$ urea and $40 \%$ formamide). The gels were run at $60^{\circ} \mathrm{C}$ for $5.5 \mathrm{~h}$ at a constant voltage of $120 \mathrm{~V}$. After electrophoresis, the gels were stained with ethidium bromide for $15 \mathrm{~min}$ and photographed on a u.v. transillumination table with a Gel Documentation System (Gel Doc 2000 ${ }^{\mathrm{TM}}$, Bio-RaD LaboratoriesSegrate, Milan, Italy).

\section{Sequence analysis of bands excised from DGGE} gels

Bands chosen for sequence analysis were carefully excised from the DGGE gel with a sterile scalpel, and then placed in 2-ml sterilized screw-cap polypropylene tubes, with $60 \mu \mathrm{l}$ TE buffer. The DNA was allowed to passively diffuse into water at $4^{\circ} \mathrm{C}$ overnight. $5 \mu$ of the eluate was used as template DNA for a PCR performed with the primers and conditions described above for environmental samples. The PCR products

Table 1 Influent and effluent characteristics of the two systems in April 2004

\begin{tabular}{|c|c|c|c|c|c|c|}
\hline Item & $\mathrm{COD}_{\mathrm{Cr}}(\mathrm{mg} / \mathrm{l})$ & BOD (mg/l) & $\mathrm{NH}_{4}^{+}-\mathrm{N}(\mathrm{mg} / \mathrm{l})$ & $\mathrm{TN}(\mathrm{mg} / \mathrm{l})$ & $\mathrm{TP}(\mathrm{mg} / \mathrm{l})$ & $\mathrm{SS}(\mathrm{mg} / \mathrm{l})$ \\
\hline Raw sewage & $310-400$ & $180-200$ & $35.6-47.5$ & $49.0-62.0$ & $5.2-6.6$ & $260-350$ \\
\hline $\mathrm{A}_{2} \mathrm{O}$ effluent & $30.2-35.6$ & $8.5-13.4$ & $11.0-25.0$ & $36.0-41.0$ & $0.6-3.8$ & $8.0-12.0$ \\
\hline $\mathrm{AO}$ effluent & $33.1-37.6$ & $9.3-12.5$ & 8.6-17.8 & $33.6-38.5$ & $5.3-5.9$ & $10.5-13.5$ \\
\hline
\end{tabular}


Table 2 PCR primers used in this study

\begin{tabular}{|c|c|c|c|c|c|c|c|c|c|}
\hline \multirow[t]{3}{*}{ Target } & \multirow[t]{3}{*}{ Primers } & \multirow{3}{*}{$\begin{array}{l}\text { Number } \\
\text { of cycles }\end{array}$} & \multicolumn{6}{|c|}{ PCR conditions } & \multirow[t]{3}{*}{ References } \\
\hline & & & \multicolumn{2}{|c|}{ Denaturation } & \multicolumn{2}{|c|}{ Annealing } & \multicolumn{2}{|c|}{ Elongation } & \\
\hline & & & ${ }^{\circ} \mathrm{C}$ & $\min$ & ${ }^{\circ} \mathrm{C}$ & $\min$ & ${ }^{\circ} \mathrm{C}$ & $\min$ & \\
\hline \multicolumn{10}{|l|}{ First PCR round } \\
\hline Actinomycetes & F243, R1378r & 35 & 95 & 1 & 63 & 1 & 72 & 2 & $\begin{array}{l}\text { Heuer } \\
\quad \text { et al. (1997) }\end{array}$ \\
\hline $\begin{array}{l}\text { Ammonia } \\
\text { oxidizers }\end{array}$ & $\begin{array}{c}\text { CTO189fAB, } \\
\text { CTO189Fc, } \\
\text { CTO654r }\end{array}$ & 35 & 95 & 1 & 57 & 1 & 72 & 1 & $\begin{array}{l}\text { Kowalchuk } \\
\text { et al. (1998) }\end{array}$ \\
\hline \multicolumn{10}{|c|}{ Second PCR round } \\
\hline Bacteria & GC-P338f, P518r & 30 & 95 & 1 & 55 & 1 & 72 & 1 & $\begin{array}{l}\text { Òvreas } \\
\quad \text { et al. (1997) }\end{array}$ \\
\hline Yeast & GC-NL1, LS2 & 30 & 95 & 1 & 55 & 1 & 72 & 1 & $\begin{array}{l}\text { Cocolin } \\
\text { et al. (2000) }\end{array}$ \\
\hline
\end{tabular}

Before each run of cycles, the temperature was held at $95^{\circ} \mathrm{C}$ for $5 \mathrm{~min}$, and after each run the temperature was kept at $72^{\circ} \mathrm{C}$ for $10 \mathrm{~min}$ for final template elongation

(40 $\mu \mathrm{l})$ were sent to Shanghai Genecore Biotechnology Company for sequence analysis.

FISH analysis and cell counting

Before hybridization, the samples were dispersed into individual cells by ultrasonication, then immediately processed and fixed in $4 \%$ paraformaldehyde for $3 \mathrm{~h}$ at $4^{\circ} \mathrm{C}$. After that, the biomass was washed with phosphate buffered saline $(\mathrm{pH} 7.4)$ and stored at a 1:1 ratio of phosphate-buffered saline and $100 \%$ ethanol at $-20^{\circ} \mathrm{C}$

All hybridizations were performed at $46^{\circ} \mathrm{C}$ for $120 \mathrm{~min}$ as described by Manz et al. (1992). The $16 \mathrm{~S}$ rRNA-targeted oligonucleotide probes and the stringency used in this study are listed in Table 3. After hybridization, the slides were mounted with Citifluor (Ted Pella Inc., Redding, CA, USA) to avoid bleaching and examined with an Axioskop 2 epifluorescent microscope (Carl Zeiss, Jena, Germany). All image processing and analysis were performed with the standard software package provided by Zeiss (Axio Vision 4.1).

Three probes are listed in Table 3. Nso190, Nsv443, and NEU were used for detecting AOB. DAPI stained bacteria were counted as the total bacterial number. Cell counts were determined by enumerating at least 1,000 cells per view and more than 10 fields were obtained for each sample.

\section{Results}

DGGE analysis results

DGGE gels for analysing eubacteria, actinomycetes, AOB, and yeast of the two systems in April 2004 are shown in Figs. 3-6, respectively, and the samples

Table 3 Oligonucleotide probes

\begin{tabular}{|c|c|c|c|c|c|c|}
\hline Probe & Specificity & Probe sequence $\left(5^{\prime}-3^{\prime}\right)$ & $\begin{array}{l}\text { Target site } \\
\text { (16S rRNA } \\
\text { positions) }\end{array}$ & $\%$ FA & $\begin{array}{l}\mathrm{NaCl} \\
(\mathrm{mM})\end{array}$ & References \\
\hline EUB338 & Bacteria & GCTGCCTCCCGTAGGAGT & $338-355$ & 20 & 225 & Amann et al. (1990) \\
\hline Nso190 & $\begin{array}{l}\text { Ammonia-oxidizing } \\
\beta \text {-subclass } \\
\text { Proteobacteria }\end{array}$ & CGATCCCCTGCTTTTCTCC & 190-208 & 55 & 20 & Mobarry et al. (1996) \\
\hline Nsv443 & Nitrosospira spp. & CCGTGACCGTTTCGTTCCG & $444-462$ & 30 & 112 & Mobarry et al. (1996) \\
\hline NEU & $\begin{array}{l}\text { Halophilic and } \\
\text { halotolerant } \\
\text { members of the } \\
\text { genus Nitrosomonas }\end{array}$ & ССССТСТGСТGCAСТСТА & $653-670$ & 40 & 56 & Mobarry et al. (1996) \\
\hline
\end{tabular}




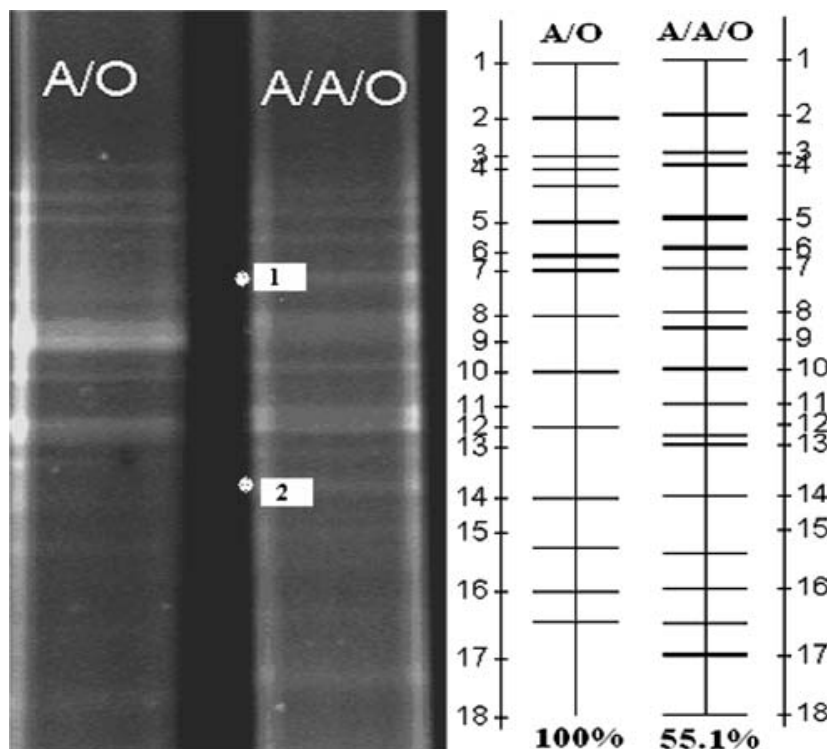

Fig. 3 DGGE analysis of bacteria communities and lane comparison in the two systems. The left side shows the DGGE patterns of activated sludge samples taken from the aeration tanks of the $\mathrm{A}_{2} \mathrm{O}$ system and the $\mathrm{AO}$ system, respectively. The right side gives the analysis results of lane comparison from the DGGE patterns using Quantity One 4.3.0 software. Bands 1 and 2 of the $\mathrm{A}_{2} \mathrm{O}$ system were excised from DGGE gel for sequencing

collected in May and June 2004 also gave similar results (data not shown). It was found that the two systems harbored quite different microbial communities,
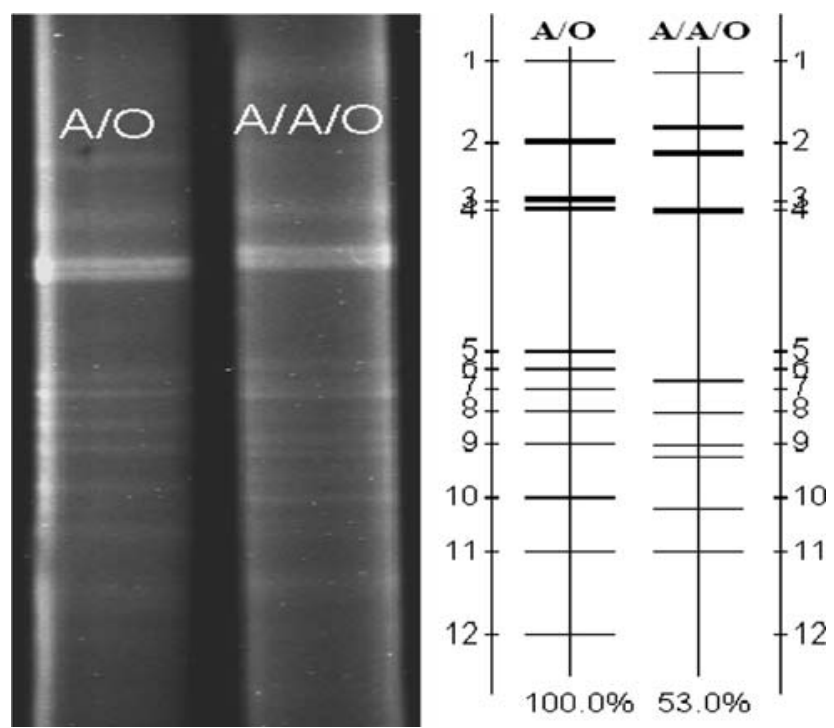

Fig. 4 DGGE analysis of actinomycetic communities and lane comparison in the two systems. The left side shows the DGGE patterns of activated sludge samples taken from aeration tanks of the $\mathrm{A}_{2} \mathrm{O}$ system and the $\mathrm{AO}$ system, respectively. The right side gives the analysis results of lane comparison from the DGGE patterns using Quantity One 4.3.0 software

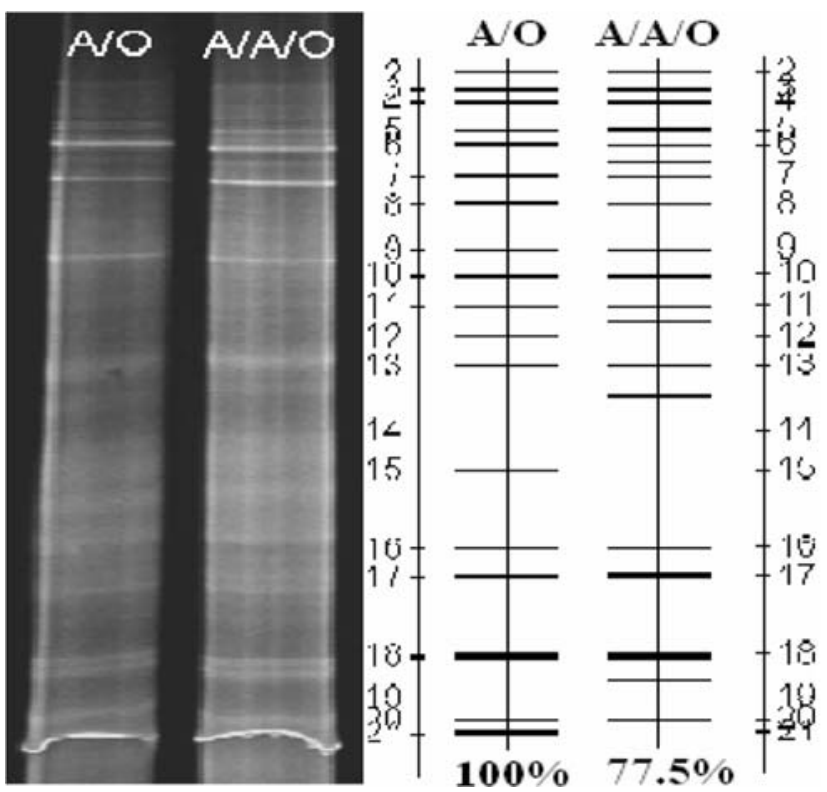

Fig. 5 DGGE analysis of AOB communities and lane comparison in the two systems. The left side shows the DGGE patterns of activated sludge samples taken from the aeration tanks of the $\mathrm{A}_{2} \mathrm{O}$ system and the AO system, respectively. The right side gives the analysis results of lane comparison from the DGGE patterns using Quantity One 4.3.0 software

and the similarities for bacteria, actinomycetes and yeast in the two systems were $55.1 \%, 53.0 \%$ and $52.8 \%$, respectively, although they received identical sewage and showed similar treatment performance. The band numbers for bacteria, actinomycetes and yeast in the $\mathrm{A}_{2} \mathrm{O}$ system were 15,10 and 26 , compared with 11,7 and 20 in the AO system, indicating that the $\mathrm{A}_{2} \mathrm{O}$ system tends to harbor richer community structures of these groups.

The two main bands of bacteria which only existed in the $\mathrm{A}_{2} \mathrm{O}$ system were excised from the DGGE gel and sent for sequencing. The sequences reported in this study are available in GenBank under accession nos. AY338406 and AY338407.

The two systems, however, contained similar AOB compositions. The similarity of the two systems was $77.5 \%$. The main bands were excised from the DGGE gel and sent for sequencing. The sequences reported in this study are available in GenBank under accession no. DQ196226 to DQ196234. Sequence analysis of $16 \mathrm{~S}$ rRNA genes revealed that all bands were closely related to Nitrosomonas spp.

Sequence analysis results of yeast bands

Major bands of the DGGE gel were excised from the $\mathrm{A}_{2} \mathrm{O}$ lane in Fig. 6 and sent for sequencing. These sequence data have been submitted to the GenBank 


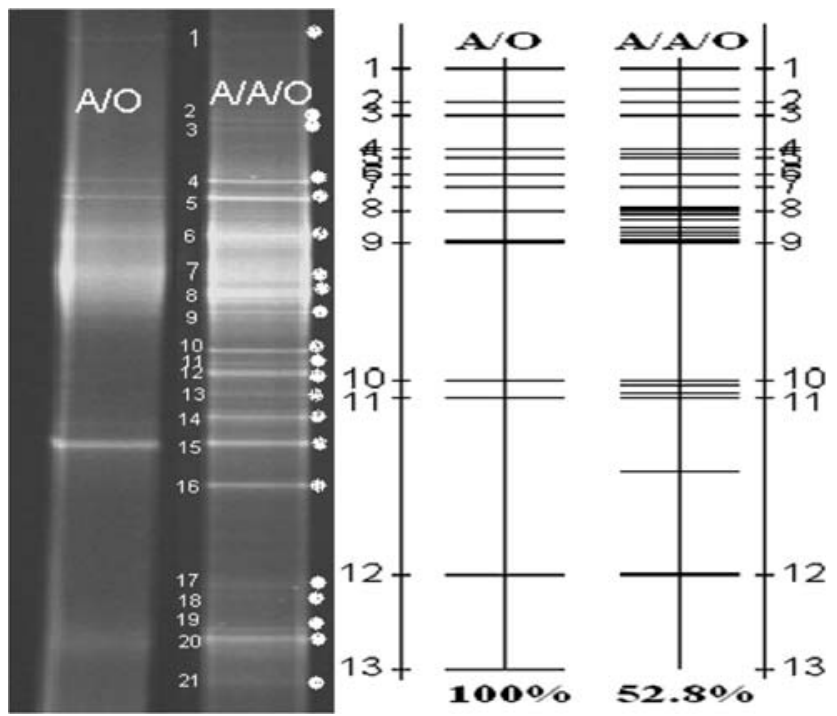

Fig. 6 DGGE analysis of yeast communities and lane comparison in the two systems. The left side shows the DGGE patterns of activated sludge samples taken from aeration tanks of the $\mathrm{A}_{2} \mathrm{O}$ system and the $\mathrm{AO}$ system, respectively. The right side gives the analysis results of lane comparison from the DGGE patterns using Quantity One 4.3.0 software

databases under accession number DQ105591 to DQ105609 and are shown in Table 4. It is interesting that there were many kinds of yeast, such as Candida maltosa, Malassezia sp., Basidiomycete yeast sp. etc., appeared in activated sludge and both systems demonstrated very diverse compositions.

FISH analysis of AOB in activated sludge

In this study, multiple probes were used for the analysis of AOB in the two systems. Probes Nsv443, NEU, and
Nso190 were respectively used for detecting bacteria belonging to the Nitrosospira cluster, and the halophilic and halotolerant Nitrosomonas cluster, and the total AOB (Table 3). All samples collected in April, May and June 2004 gave similar results. It was found that in the two systems, the genus Nitrosomonas were accounted for about $1.8 \%$ (the $\mathrm{A}_{2} \mathrm{O}$ system) and $1.6 \%$ (the AO system) respectively. The Nitrosospira proportions in the two systems were $2.2 \%$ (the $\mathrm{A}_{2} \mathrm{O}$ system) and $1.2 \%$ (the $\mathrm{AO}$ system) respectively. Hybridizations with probe Nso190 showed that the total $\mathrm{AOB}$ number in the $\mathrm{A}_{2} \mathrm{O}$ system on average accounted for $3.6 \pm 0.2 \%$ of the total bacterial population, while that in the AO system was only $1.9 \pm 0.2 \%$.

\section{Discussion}

Before reconstruction, the two systems were of the same design. One of the two systems was reconstructed into an $\mathrm{A}_{2} \mathrm{O}$ system by changing a part of the aeration basin into an anaerobic basin to enhance the phosphate removal efficiency. After reconstruction, the $\mathrm{A}_{2} \mathrm{O}$ system had a smaller aeration compartment than the AO system. However, the two systems still received identical sewage. As shown in Table 1 the two systems demonstrated almost identical performance in the removals of $\mathrm{COD}, \mathrm{BOD}$ and $\mathrm{SS}$, while the $\mathrm{AO}$ system had a slightly higher ammonia removal and the $\mathrm{A}_{2} \mathrm{O}$ system had a higher phosphate removal.

Even though the systems received identical sewage, and in spite of the quite similar constitutions, operational conditions, and treatment performance, the two systems demonstrated quite different microbial
Table 4 Sequence analysis of yeast bands excised from DGGE gels of the $\mathrm{A}_{2} \mathrm{O}$ system

\begin{tabular}{llcl}
\hline DGGE band & Accession number & $\%$ Identity & Most closely related bacterial sequence \\
\hline 1 & DQ105591 & $100 \%$ & Uncultured organism clone ASt-35 \\
2 & DQ205592 & $94 \%$ & Uncultured organism clone ASt-35 \\
3 & DQ105593 & $95 \%$ & Uncultured organism clone ASt-1 \\
4 & DQ105594 & $86 \%$ & Uncultured mycorrhiza clone 1287 \\
5 & DQ105595 & $96 \%$ & Uncultured organism clone ASt-1 \\
6 & DQ105596 & $96 \%$ & Uncultured organism clone ASt-35 \\
7 & DQ205597 & $97 \%$ & Uncultured organism clone ASt-1 \\
8 & DQ105598 & $94 \%$ & Uncultured fungus clone FF36 \\
9 & DQ105599 & $100 \%$ & Candida maltosa \\
10 & DQ105600 & $97 \%$ & Uncultured organism clone ASt-35 \\
12 & DQ105601 & $98 \%$ & Entyloma ranunculi-repentis \\
13 & DQ105602 & $97 \%$ & Malassezia sp. \\
14 & DQ105603 & $97 \%$ & Entyloma lobeliae \\
15 & DQ105604 & $98 \%$ & Entyloma fuscum \\
16 & DQ105605 & $100 \%$ & Geotrichum fragrans \\
17 & DQ105606 & $100 \%$ & Dipodascus tetrasperma \\
18 & DQ105607 & $91 \%$ & Candida sp. \\
20 & DQ105608 & $96 \%$ & Basidiomycete yeast sp. \\
21 & DQ105609 & $98 \%$ & Plasmodiophora brassicae \\
\hline
\end{tabular}


community structures except for AOB. It is interesting that the $\mathrm{A}_{2} \mathrm{O}$ system had much richer compositions of bacterial, actinomycotic, and yeast populations. The richer community structures of these populations were obviously related to the creation of the anaerobic compartment. Most of the increased species in the $\mathrm{A}_{2} \mathrm{O}$ system might be the ones that tend to grow under anaerobic environments. Phosphate accumulation organisms (PAOs) should be the one category of population that increased through the creation of an anaerobic compartment. The $\mathrm{A}_{2} \mathrm{O}$ process is an enhanced biological phosphorus removal (EBPR) process and PAOs play the key role in phosphorus removal in EBPR systems (Okunuki et al. 2004). Table 1 indicates that the AO system had almost no phosphate removal ability. The $\mathrm{A}_{2} \mathrm{O}$ system, on the other hand, had a TP removal of about $50 \%$, which should be attributed to the possible accumulation of PAOs. The sequencing results of bacterial DGGE bands indicate that the two dominant populations (AY338406, AY338407) appearing solely in the $\mathrm{A}_{2} \mathrm{O}$ system belong to the gamma proteobacteria. Bacteria of the gamma proteobacteria have been considered to be related with phosphate removal (Wentzel 1988; Kavanaugh and Randall 1994).

The relatively low TP removal in the $\mathrm{A}_{2} \mathrm{O}$ system, on the other hand, was perhaps related to the relatively high residual nitrate coming from the anoxic compartment. The nitrate concentration of mixed liquor in the anoxic compartment was as high as $15.9 \mathrm{mg} / \mathrm{l}$, which could be used as sufficient electron acceptors for denitrifying bacteria to utilize organic substrates. The competition between denitrifying bacteria and PAOs for organic compounds might be the main reason of the low TP removal (Hascoet and Florentz 1985; Kuba et al. 1994).

It is interesting that the two systems had a very rich yeast population. Yeast tends to occur in environments with high salt and/or substrate concentrations, such as the boundary between the terrestrial environment and the ocean (Gadanho et al. 2003), and can grow well under low moisture and low $\mathrm{pH}$ conditions relative to bacteria (Chigusa et al. 1989). Organic substrates can foster yeast growth. However, yeast has been traditionally used in high load, high salt, and high substrate concentration processes such as the fermentation, brewing and soy sauce industries. Recent studies show that yeasts have advantages in treating high strength oily wastewater and monosodium glutamate-manufacturing wastewater over the conventional bacteriadominating processes (Yang et al. 2003, 2005). Its existence and ecological role in activated sludge, however, has long been neglected. The yeast DGGE patterns in Fig. 6 and the sequencing results in Table 4 show that many yeast populations including Candida sp., Malassezia sp. and Basidiomycete sp. etc. existed in both systems. The exact roles and the ecological significance of yeasts in wastewater treatment processes, however, are still unknown and need further research.

Actinomycetes in activated sludge have recently become the focus of research because they are believed to play an important role in sludge bulking and foaming in activated sludge plants (Madoni et al. 2000; Davenport et al. 2000). Their hydrophobic cell surface is supposed to support adherence and stabilization of interfaces and thus promote sludge flotation, leading to a higher SVI (Gisi et al. 1998). The average SVIs of the two systems were $150 \mathrm{l} / \mathrm{g}\left(\mathrm{A}_{2} \mathrm{O}\right)$ and $100 \mathrm{l} / \mathrm{g}$ (AO) respectively. The richer actinomycete population in the $\mathrm{A}_{2} \mathrm{O}$ system suggests that some actinomycetes might be related to its higher SVI. Apart from these negative roles, actinomycetes are active in the decomposition of organic materials (McCarthy 1987). The diversity of actinomycetes in the two systems suggests that some actinomycetes might also play an important role in the removal of organic substance. Further investigation, however, is required to draw a conclusion.

Of the four populations analysed, only AOB communities demonstrated a clear similarity $(77.5 \%)$ between the two processes, suggesting that the introduction of the anaerobic compartment did not change the richness of AOB populations markedly. However, as shown in the FISH analysis results, the proportion of AOB to total bacterial numbers in the two systems was quite different $\left(3.6 \pm 0.2 \%\right.$ for $\mathrm{A}_{2} \mathrm{O}$ system and $1.9 \pm 0.2 \%$ for $\mathrm{AO}$ system). Obviously, the $\mathrm{A}_{2} \mathrm{O}$ system had much more AOB cells than the AO system. Previous study (Limpiyakorn et al. 2005) showed that SRT mainly influenced the total numbers of AOB in activated sludge systems. But in this study, the two systems had similar SRT as well as MLSS. Further studies are necessary to carry out in order to explain this phenomenon completely.

\section{Conclusion}

The addition of an anaerobic compartment in the $\mathrm{A}_{2} \mathrm{O}$ system had an important impact on microbial communities and biodiversity, leading to much richer microbial community structures of bacterial, actinomycetic and yeast groups. The band numbers for bacteria, actinomycetes and yeast in the $\mathrm{A}_{2} \mathrm{O}$ system were 15, 10 and 26, compared with 11,7 and 20 in the AO system. The structure of the AOB group in the two systems, on the other hand, demonstrated a relatively 
high similarity. The rich yeast compositions suggested that yeast might play some important roles in pollutant removal.

Acknowledgements This work was funded by the international cooperation project of the National Natural Science Foundation of China (No. 20510076). We appreciate the assistance provided by Beijing Drainage Group Co., Ltd. in the sampling work.

\section{References}

Amann RI, Ludwig W, Schleifer KH (1995) Phylogenetic identification and in situ detection of individual microbial cells without cultivation. Microbiol Rev 59:143-169

Amann RI, Krumholz L, Stahl DA (1990) Fluorescentoligonucleotide probing of whole cells for determinative, phylogenetic, and environmental studies in microbiology. J Bacteriol 172:762-770

Ballinger SJ, Head IM, Curtis TP, Godley AR (1998) Molecular microbial ecology of nitrification in an activated sludge process treating refinery wastewater. Water Sci Technol 37:105-108

Bollmann A, Laanbroek HJ (2002) Influence of oxygen partial pressure and salinity on the community composition of ammonia-oxidizing bacteria in the Schelde estuary. Aqua Microbial Ecol 28:239-247

Boon N, Windt WD, Verstraete W, Top EM (2002) Evaluation of nested PCR-DGGE (denaturing gradient gel electrophoresis) with group-specific $16 \mathrm{~S}$ rRNA primers for the analysis of bacterial communities from different wastewater treatment plants. FEMS Microbiol Ecol 39:101-112

Chen S, Xu M, Cao H (2004) The activated-sludge fauna and performance of five sewage treatment plants in Beijing China. Eur J Protistol 40:147-152

Chigusa K, Nishi N, Matsumaru Y, Minegishi Y (1989) Treatment of food manufacturing wastewater by Yeast. J Environ Pollut Control 25:1557-1563 (In Japanese)

Cocolin L, Bisson LF, Mills DA (2000) Direct profiling of the dynamics in wine fermentations. FEMS Microbiol Lett 189:81-87

Curds CR (1982) The ecology and role of protozoa in aerobic sewage treatment processes. Annu Rev Microbiol 36:27-46

Curds CR, Cockburn A (1970) Protozoa in biological sewage treatment process-II. Protozoa as indicators in the activated sludge process. Water Res 4:237-249

Davenport RJ, Curtis TP, Goodfellow M, Stainsby FM, Bingley M (2000) Quantitative use of fluorescent in situ hybridization to examine relationships between mycolic acid-containing actinomycetes and foaming in activated sludge plants. Appl Environ Microbiol 66:1158-1166

Gadanho M, Almeida JMGCF, Sampaio JP (2003) Assessment of yeast diversity in a marine environment in the south of Portugal by microsatellite-primed PCR. Anton Leeuw $84: 217-227$

Gisi D, Willi L, Traber H, Leisinger T, Vuilleumier S (1998) Effects of bacterial host and dichloromethane dehalogenase on the competitiveness of methylotrophic bacteria growing with dichloromethane. Appl Environ Microbiol 64:11941202

Hascoet MC, Florentz M (1985) Influence of nitrates on biological phosphorus removal from wastewater. Water SA (Pretoria) 11:1-8
Heuer H, Krsek M, Baker P, Smalla K, Wellington EM (1997) Wellington, analysis of actinomycete communities by specific amplification of genes encoding 16S rRNA and gelelectrophoretic separation in denaturing gradients. Appl Environ Microbiol 63:3233-3241

Kavanaugh RG, Randall CW (1994) Bacterial populations in a biological nutrient removal plant. Water Sci Technol 29: $25-34$

Kowalchuk GA, Bodelier PLE, Heilig GHJ, Stephen JR, Laanbroek HJ (1998) Community analysis of ammonia-oxidising bacteria, in relation to oxygen availability in soils and root-oxygenated sediments, using PCR, DGGE and oligonucleotide probe hybridization. FEMS Microbiol Ecol 27:339-350

Kuba T, Wachtmeister A, van Loosdrecht MCM, Heijnen JJ (1994) Effect of nitrate on phosphorus release in biological phosphorus removal systems. Water Sci Technol 30:263-269

Limpiyakorn T, Shinohara Y, Kurisu F, Yagi O (2005) Communities of ammonia-oxidizing bacteria in activated sludge of various sewage treatment plants in Tokyo. FEMS Microbiol Ecol 54:205-217

Madoni P, Davoli D, Chierici E (1993) Comparative analysis of the activated sludge microfauna in several sewage treatment works. Water Res 27:1485-1491

Madoni P, Davol D, Gibin G (2000) Survey of filamentous microorganisms from bulking and foaming activated-sludge plants in Italy. Water Res 34:1767-1772

Manz W, Amann R, Ludwig W, Wagner M, Scheifer K-H (1992) Phylogenetic oligodeoxynucleotide probes for the major subclasses of Proteobacteria: problems and solutions. System Appl Microbiol 15:593-600

McCarthy AJ (1987) Lignocellulose-degrading actinomycetes. FEMS Microbiol Rev 46:145-163

Miller N, Bryant JE, Madsen EL, Ghiorse WC (1999) Evaluation and optimization of DNA extraction and purification procedures for soil and sediment samples. Appl Environ Microbiol 65:4715-4724

Mobarry BK, Wagner M, Urbain V, Rittmann BE, Stahl DA (1996) Phylogenetic probes for analyzing abundance and spatial organization of nitrifying bacteria. Appl Environ Microbiol 62:2156-2162

Muyzer G, de Waal EC, Uitterlinden A (1993) Profiling of complex microbial populations using denaturing gradient gel electrophoresis analysis of polymerase chain reactionamplified genes coding for 16S Rrna. Appl Environ Microbiol 59:695-700

Òvreas L, Forney L, Daae FL, Torsvik V (1997) Distribution of bacterioplankton in meromictic lake Saelevannet, as determined by denaturing gradient gel electrophoresis of PCRamplified gene fragments coding for 16S Rrna. Appl Environ Microbiol 63:3367-3373

Okunuki S, Kawaharasaki M, Hideo Tanaka H, Kanagawa T (2004) Changes in phosphorus removing performance and bacterial community structure in an enhanced biological phosphorus removal reactor. Water Res 38:2433-2439

Paniagua-Michel J, Franco-Rivera A, Cantera JJL, Stein LY (2005) Activity of nitrifying biofilms constructed on lowdensity polyester enhances bioremediation of a coastal wastewater effluent. World J Microbiol Biotechnol 21:13711377

Rowan AK, Snape JR, Fearnside D, Barer MR, Curtis TP, Head IM (2003) Composition and diversity of ammonia-oxidising bacterial communities in wastewater treatment reactors of different design treating identical wastewater. FEMS Microbiol Ecol 43:195-206 
Schloss PD, Hay AG, Wilson DB, Walker LP (2003) Tracking temporal changes of bacterial community fingerprints during the initial stages of composting. FEMS Microbiol Ecol 46:1-9

Wagner M, Rath G, Amann R, Koops HP, Schleifer KH (1995) In situ identification of ammonia-oxidizing bacteria. System Appl Microbiol 18:251-264

Wentzel MC, Loewenthal RE, Ekama GA, Marais GR (1988) Enhanced polyphosphate organism cultures in activated sludge systems, Part 1. Enhanced culture development, Water SA (Pretoria) 14:81-92
Yang Q, Yang M, Hei L, Zheng S (2003) Using ammoniumtolerant yeast isolates: Candida halophila and Rhodotorula glutinis to treat high strength fermentative wastewater. Environ Technol 24:383-390

Yang Q, Yang M, Zhang S, Lv W (2005) Treatment of wastewater from a monosodium glutamate manufacturing plant using successive yeast and activated sludge systems. Process Biochem 40:2483-2488

Zheng X, Yang H, Li D (2005) Change of microbial populations in a suspended-sludge reactor performing completely autotrophic N-removal. World J Microbiol Biotechnol 21:843-850 